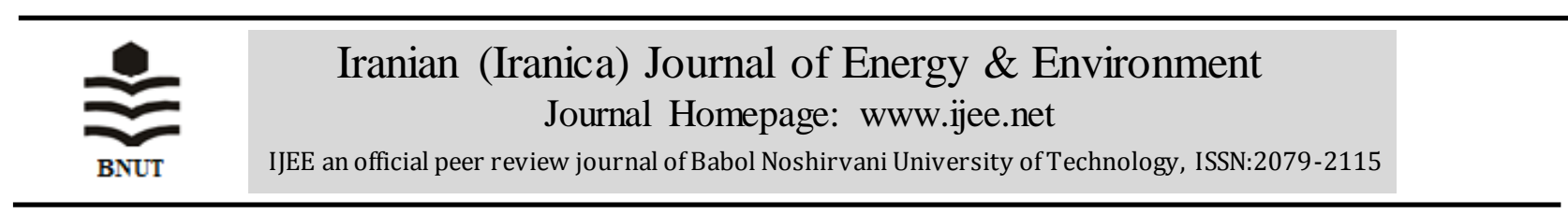

\title{
Application of Response Surface Methodology for Sago Wastewater Treatment by Ozonation
}

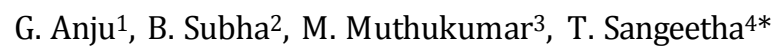 \\ ${ }_{1}^{1}$ School of Ocean Engineering and Underwater Technology, Kerala University of Fisheries and Ocean studies, Panangad, Kerala, In dia \\ ${ }^{2}$ Department of Environmental Engineering, Korea Maritime and Ocean University, Busan, South Korea \\ ${ }^{3}$ Department of Environmental Science, School of Earth Science Systems, Central University of Kerala, Kerala, India \\ ${ }^{4}$ Department of Energy and Refrigerating Air-Conditioning Engineering, Research Centre of Energy Conservation for New Generation of \\ Residential, Commercial, and Industrial Sectors, National Taipei University of Technology, Taipei, Taiwan
}

\section{PAPER I NFO}

\section{Paper history:}

Received 15 March 2019

Accepted in revised form 24 June 2019

\section{Keywords:}

Central Composite Design

Chemical Oxygen Demand

Ozonation

Sago Wastewater

Response Surface Methodology

\section{$A B S T R$ R A $C$ T}

A treatment method based on the degradation of sago processing wastewater using ozonation process was conducted in this research study. The optimization of the process variables was designed with the aid of software called Design Expert and the technique was called response surface methodology (RSM) in Central composite design. The effect of ozonation variables like $\mathrm{pH}$, treatment time and ozone concentration on the reduction of chemical oxygen demand (COD) of sago waste water was investigated. Interestingly, two different types of results like maximum removal of COD and optimum removal of COD were observed. Maximum COD removal of $62.45 \%$ was at $\mathrm{pH} 9.8$, ozonation time $95.7 \mathrm{~min}$, ozone dose $42 \%$ and optimum COD removal 0 f $56.7 \%$ was at $\mathrm{pH}$ 9.8, ozonation time $35.7 \mathrm{~min}$, and ozone dose $42 \%$. Bacterial count was found to be nil after ozonation and microscopic observation of biomass proved that the sludge content had effectively reduced after ozonation treatment. It was determined that the ozonation of sago wastewater was a promising effort in wastewater treatment.

doi: $10.5829 /$ ijee.2019.10.02.05

\section{INTRODUCTION}

Tapioca (Manihot esculenta) is concentrated in the southem peninsular region of India in the states of Tamil Nadu and Andhra Pradesh. Sago, the edible starch globules processed from the tubers of tapioca, is the staple diet of middle income populations in India. The tubers are the raw material and they are converted into commercial sago through indigenous technology [1]. There are more than 1000 sago industries in Tamil Nadu and in that $80 \%$ are in Salem district. They produce about 15 to 30 tonnes of sago per industry/day and discharge about 40,000 to 50,000 litres of sago wastewater per tonne of sago. They generate more than $85 \%$ of the total wastewater output and about 400 units discharge directly into rivers. Sago wastewater is complex and acidic in nature with high organic matter, intense COD and BOD, suspended solids, obnoxious odour and irritating colour [2]. Many investigators reported that the wastewater from sago mills are of serious concern and the Central Pollution Control Board (CPCB) has classified sago industries as "Red" industries Most of the low cost and conventional treatment methods have low treatment efficiency due to high concentration of suspended solids and insoluble fibres present in the wastewater [3]. According to literature various technologies have been implied to treat sago wastewater. Some widely used methods are high-rate anaerobic treatment such as Microbes [4]; anaerobic reactors [5-8], Three phase fluidized bed bioreactor [9]; activated sludge and cow dung slurry [10], sago-sludge treatment using earthworm [11] and utilizing sago waste as an adsorbent for removing $\mathrm{Cu}$ ions [12].

Ozone is the triatomic form of oxygen, which is composed of three oxygen atoms. It is a powerful oxidizing agent with high oxidation potential $(\mathrm{Eo}=2.07 \mathrm{~V})$ compared to chlorine $(\mathrm{Eo}=1.36 \mathrm{~V})$ and $\mathrm{H}_{2} \mathrm{O}_{2}(\mathrm{Eo}=1.78 \mathrm{~V})$ which on dissolution in an aqueous medium can react with a variety of organic molecules to cause partial oxidation or complete mineralization, i.e. $\mathrm{CO}_{2}$ and water [13]. The use of ozone was first pioneered in the early 1970's and has been successfully used in a vast number of applications. Various types of organic and inorganic wastewaters like distillery wastewater [14], drinking water [15], domestic wastewater [16], textile wastewater [17] Landfill leachate [18] have been successfully treated by ozonation. The main effects of ozonation are decolorization, elimination of taste and odors, degradation of organics and disinfection. The advantage of ozonation is that its final products are $\mathrm{CO}_{2}$ and $\mathrm{H}_{2} \mathrm{O}$ and the residual ozone in the system changes in few minutes to oxygen $\left(\mathrm{O}_{2}\right)$.

RSM is a mathematical and statistical technique that is 
useful for the optimization of chemical reactions and industrial processes and is commonly used for experimental designs [19]. It is an efficient statistical tool to optimize the operating conditions in multivariable systems by considering the interactions between variables. Using RSM, with a minimum number of experiments, an optimal response could be achieved [20,21]. The objective of this research study was to evaluate the COD removal efficiency in starch processing wastewater employing ozonation process and optimizing it by response surface methodology (RSM) in central composite design. Mathematical correlations between $\mathrm{pH}$, ozonation time and ozone dose on the removal of COD in wastewater were estimated.

\section{EXPERIMENTAL PROTOCOLS}

\section{Wastewater and its characterisation}

Sago wastewater was collected from SPAC Tapioca Products (India) Ltd Erode district, Tamil Nadu, India. Sample collection and characterization was performed according to the standard methods [22] and initial parameters analysed are tabulated in Table 1.

\section{Experimental setup}

Schematic diagram of the lab-scale experimental set up is shown in Figure 1. It consisted of an oxygen concentrator $\left(\mathrm{SimO}_{2}\right.$ plus, Italy), ozone generator (Ozonetek Ltd., India) with built-in oil-free compressor and reaction column. A controlled flow rate of $2 \mathrm{~L} / \mathrm{min}$ of oxygen was used to produce $2 \mathrm{~g} / \mathrm{h}$ of ozone. The reactor consisted of a glass column of $72 \mathrm{~cm}$ height, outer diameter of $4.5 \mathrm{~cm}$, an inner diameter of $3.5 \mathrm{~cm}$ and holding capacity of $1500 \mathrm{~mL}$ of effluent. It also had sample ports at various points, an ozone gas inlet at the bottom with an air diffuser over the inlet port to diffuse the oxygen/ozone gas mixture through the column, and a closed top with a collection port to collect the unreacted ozone gas. Teflon tube was used for connecting the ozone outlet port from the ozone generator to the ozone reaction chamber.

\section{Experimental procedure}

Ozonation process The sample was transferred to the ozonation chamber and ozone was passed into the sample. The ozonation dose was varied from $10-50 \%$ and the ozonation time was varied from 1-121 minutes to investigate

TABLE 1. Initial Physicochemical parameters for the Sago effluent

\begin{tabular}{lc}
\hline Parameters & Values \\
\hline $\mathrm{pH}$ & $4-5$ \\
$\mathrm{COD}$ & $7700 \mathrm{mg} / \mathrm{L}$ \\
Total Suspended Solids (TSS) & $3000 \mathrm{mg} / \mathrm{L}$ \\
Volatile Suspended Solids (VSS) & $1600 \mathrm{mg} / \mathrm{L}$ \\
Phosphate & $45 \mathrm{mg} / \mathrm{L}$ \\
Carbohydrate & $10 \mathrm{mg} / \mathrm{L}$ \\
Starch & $5 \mathrm{mg} / \mathrm{L}$ \\
Sulphate & $65 \mathrm{mg} / \mathrm{L}$ \\
\hline
\end{tabular}

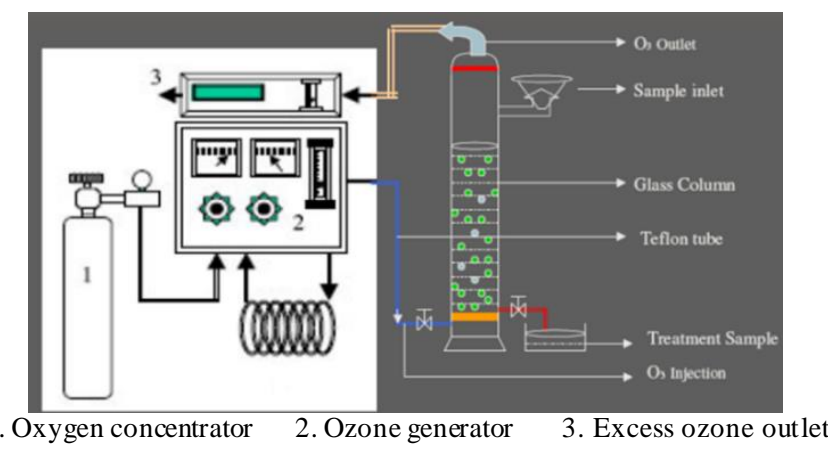

Figure 1. Schematic representation of the experimental set up employed in this study

the effects of ozonation parameters on COD removal. After ozonation, the sample was transferred in to a $500 \mathrm{~mL}$ conical flask and sealed tightly with a rubber cork. The experiment was carried out at room temperature [23].

Central composite design procedure Response surface methodology (RSM) consists of statistical tools and techniques for estimating functional relationship between variables and responses [24]. A three-level factorial design was established with the help of the Design Expert software (Central Composite Design Expert Version 8.0.3, Stat Ease, Minneapolis, USA). In this study, central composite design (CCD) was used for RSM in the experimental design, which is well suited for fitting a quadratic surface and usually works well for process optimization. The variables selected were $\mathrm{pH}$ $\left(\mathrm{X}_{1}\right)$ time $\left(\mathrm{X}_{2}\right)$ and ozone dosage $\left(\mathrm{X}_{3}\right)$ while the response observed was COD. The behaviour of the system was explained by the following second-degree quadratic polynomial equation.

$$
\begin{aligned}
& \mathrm{Y}=\mathrm{B}_{\mathrm{o}}+\mathrm{B}_{1} \mathrm{X}_{1}+\mathrm{B}_{2} \mathrm{X}_{2}+\mathrm{B}_{3} \mathrm{X}_{3}+\mathrm{B}_{11} \mathrm{X}_{1}^{2}+\mathrm{B}_{22} \mathrm{X}_{2}^{2}+ \\
& \mathrm{B}_{33} \mathrm{X}_{3}^{2}+\mathrm{B}_{12} \mathrm{X}_{1} \mathrm{X}_{2}+\mathrm{B}_{13} \mathrm{X}_{1} \mathrm{X}_{3}+\mathrm{B}_{23} \mathrm{X}_{2} \mathrm{X}_{3}
\end{aligned}
$$

where, $Y$ was predicted response, $B_{0}$ the constant coefficient, $\mathrm{B}_{1}, \mathrm{~B}_{2}$, and $\mathrm{B}_{3}$ the linear coefficient, $\mathrm{B}_{11}, \mathrm{~B}_{22}, \mathrm{~B}_{33}$ the quadratic coefficient, $\mathrm{B}_{11}, \mathrm{~B}_{12}, \mathrm{~B}_{13}$ the cross-products coefficient, and $\mathrm{X}_{1}, \mathrm{X}_{2}$, and $\mathrm{X}_{3}$ were input variables $(\mathrm{pH}$, ozonation time and retention time). The variables and their levels were design ated as $-1.682,-1,0,+1$, and +1.682 as in Table 2 . A total of 20 runs were essential for response optimization and the adequacy of the proposed model was then revealed by the diagnostic checking tests provided by analysis of variance (ANOVA). The quality of the fit polynomial model was expressed by the coefficient of determination $\mathrm{R}^{2}$, adjusted $\mathrm{R}^{2}$ and "adequate precision." The fitted polynomial equation was expressed as three dimensional (3D) surface plots to visualize individual and interactive effect of factors on the responses within the designed range [23].

Analytical procedure Chemical Oxygen Demand (COD) was measured in accordance with the standard methods [22]. Bacterial count analysis in the sago wastewater was performed using serial dilution and plating techniques [25]. The colony forming units (CFU) were estimated before and after ozonation treatment of the wastewater. Olympus microscope (Leica Meteor II, Germany) with digital camera at $100 \mathrm{X}$ magnification was used in this study to observe wastewater biomass before and after the experiments. 
TABLE 2. Process variables and their factorial levels

\begin{tabular}{lcccccc}
\hline Variables, & Factors & \multicolumn{5}{c}{ Levels } \\
\cline { 2 - 7 } Unit & $\mathrm{X}$ & -1.682 & -1 & 0 & +1 & +1.682 \\
\hline $\mathrm{pH}$ & $\mathrm{X} 1$ & 3 & 4.2 & 7 & 9.8 & 11 \\
Time (min) & $\mathrm{X} 2$ & 1 & 35.7 & 61 & 95.7 & 121 \\
$\begin{array}{l}\text { Ozone dose } \\
(\%)\end{array}$ & $\mathrm{X} 3$ & 10 & 18 & 30 & 42 & 50 \\
\hline
\end{tabular}

\section{RESULTS AND DISCUSSIONS}

Fitting the second order polynomial equation and statistical analysis

Several factors influence the organic removal in a wastewater during ozonation and $\mathrm{pH}$, ozonation time and dose may play vital roles. Experiments were performed to study the effect of $\mathrm{pH}$, ozone dosage and the treatment time on the substrate removal efficiency from sago wastewater using ozonation process. Table 3 shows the full factorial design of the conducted experiments and the relationship between the actual and predicted values of Y. The regression Equation (2) given below was obtained by the analysis of variance by giving the percentage level of COD reduction.

$$
\begin{aligned}
& \mathrm{Y}=+52.74+11.70 \mathrm{X}_{1}+4.49 \mathrm{X}_{2}+5.79 \mathrm{X}_{3}-9.49 \mathrm{X}_{1}{ }^{2}- \\
& 3.93 \mathrm{X}_{2}{ }^{2}-6.42 \mathrm{X}_{3}^{2}+0.25 \mathrm{X}_{1} \mathrm{X}_{2}+8.36 \mathrm{X}_{1} \mathrm{X}_{3}-3.03 \\
& \mathrm{X}_{2} \mathrm{X}_{3}
\end{aligned}
$$

\begin{tabular}{|c|c|c|c|c|c|}
\hline \multirow{2}{*}{ Run } & \multirow{2}{*}{ pH } & \multirow{2}{*}{$\begin{array}{l}\text { Ozonation } \\
\text { time (min) }\end{array}$} & \multirow{2}{*}{$\begin{array}{c}\text { Ozone } \\
\text { dose }(\%)\end{array}$} & \multicolumn{2}{|c|}{ COD removal $(\%)$} \\
\hline & & & & Experiment & Predicted \\
\hline 1 & 7 & 61 & 50 & 46.6 & 45.9 \\
\hline 2 & 4.2 & 35.7 & 18 & 17 & 16.6 \\
\hline 3 & 7 & 61 & 10 & 19 & 19.4 \\
\hline 4 & 4.2 & 95.7 & 18 & 33.7 & 33.2 \\
\hline 5 & 3 & 61 & 30 & 16.2 & 16.6 \\
\hline 6 & 11 & 61 & 30 & 45.4 & 44.5 \\
\hline 7 & 7 & 61 & 30 & 52 & 51.9 \\
\hline 8 & 7 & 61 & 30 & 51.5 & 51.9 \\
\hline 9 & 4.2 & 95.7 & 42 & 19 & 15.2 \\
\hline 10 & 4.2 & 35.7 & 42 & 15.8 & 19.8 \\
\hline 11 & 9.8 & 95.7 & 42 & 62 & 62.45 \\
\hline 12 & 7 & 61 & 30 & 51.8 & 51.9 \\
\hline 13 & 7 & 61 & 30 & 52 & 51.9 \\
\hline 14 & 7 & 1 & 30 & 25.2 & 21.8 \\
\hline 15 & 7 & 121 & 30 & 45 & 49.4 \\
\hline 16 & 9.8 & 95.7 & 18 & 41 & 37.2 \\
\hline 17 & 7 & 61 & 30 & 52.5 & 51.9 \\
\hline 18 & 9.8 & 35.7 & 42 & 56 & 56.7 \\
\hline 19 & 9.8 & 35.7 & 18 & 26 & 29.9 \\
\hline 20 & 7 & 61 & 30 & 53 & 51.9 \\
\hline
\end{tabular}

TABLE 3. Experimental and predicted COD removal values: Run 11- Maximum results; Run 18- Optimized results
$\mathrm{Y}$ is the predicted response in real value, $\mathrm{X}_{1}$ is the coded value of the variable of $\mathrm{pH}, \mathrm{X}_{2}$ is the coded value of the variable of ozonation time, and $\mathrm{X}_{3}$ is the coded value of the variable of ozone dosage. For the statistical testing of the significant model equation, Fisher's statistical test and $\mathrm{P}$ values for ANOVA were used. They indicated that the model parameters and their interactions were significant [26]. The equation in terms of coded factors can be used to predict the response for the given levels of each factor. The high levels of the factors are coded as +1 and the low levels of the factors are coded as -1 . The coded equation is useful for identifying the relative impact of the factors by comparing the factor coefficients.

Two different tests namely sequential model sum of squares and model summary statistics were employed to decide about the adequacy models to represent the COD removal and the results of these tests are tabulated in Table 4. As per sequential model sum of squares test quadratic model had a probability value of $<0.0001$, implying that the model was significant. Any factor or interaction of factors with $\mathrm{p}<$ 0.05 is considered to be significant [23]. It had maximu m adjusted and predicted $\mathrm{R}^{2}$ values of 0.9673 and 0.9828 , respectively. However, Cubic model was aliased so quadratic model was chosen for further analysis. The results showed an $F$ value of 63.36, and the large value of $F$ indicated that most of the variation in response can be explained by the regression equation. The associated $\mathrm{P}$ value was used to estimate whether $F$ was large enough to indicate statistical significance. The Predicted $\mathrm{R}^{2}$ of 0.8216 was in reasonable agreement with the Adjusted $\mathrm{R}^{2}$ of 0.9673 ; i.e. the difference was less than 0.2. Adeq Precision measured the signal to noise ratio and a ratio greater than 4 was desirable. The ratio of this study 23.813 indicated an adequate signal. Therefore, this quadratic model can be used to navigate the design space for COD. The ANOVA thus proved that the form of the model chosen to explain the relationship between the factors and the response was correct.

\section{Effect of variables on COD removal}

The initial COD value of the sample was $7700 \mathrm{mg} / \mathrm{L}$. We obtained two types of result such as maximum and optimum. Maximum was the highest COD removal in the study, which was obtained at almost the maximum parameters constraint (Run 11). Optimum was the ideal COD removal which can be obtained by an optimal requirement of parameters (Run 18). The maximum results depicted in Figure 2 illustrate an increase in the COD removal efficiency with increasing $\mathrm{pH}$, ozone dose and ozonation time and maximum removal of $62.45 \%$ at $\mathrm{pH}$ of 9.8 , ozone dose of $42 \%$ and ozonation time of $95.7 \mathrm{~min}$. Figure 2A $(1,2,3)$ show the contour graphs of the effects of the three variables on COD removal; Figure $2 \mathrm{~B}$ $(1,2,3)$ show the three dimensional surface plots for the same and overlay plot for the condition is shown in Figure 2C. The optimum results for COD removal efficiency are portrayed in Figure 3. As mentioned earlier Figure $3 \mathrm{~A}(1,2,3)$ are contours, Figure $3 \mathrm{~B}(1,2,3)$ are the $3 \mathrm{D}$ graphs and Figure $3 \mathrm{C}$ is the overlay plot for the optimized conditions. Generally, the COD removal was betterin alkaline $\mathrm{pH}(9.8)$ than at acidic $\mathrm{pH}$ (see Table 3), because at acidic $\mathrm{pH}$ the protons in the solution get reduced to $\mathrm{H}_{2}$, and thus the proportion of $\mathrm{OH}^{-}$ions produced is less and consequently there is less substrate removal [27]. The maximu m removal of COD $(61 \%)$ observed in this study 
TABLE 4. ANOVA results of the quadratic model for COD removal

\begin{tabular}{|c|c|c|c|c|c|c|}
\hline Source & Sum of squares & df & Mean square & F value & Prob> F & Remark \\
\hline Model & 5527.12 & 9 & 614.12 & 63.36 & $<0.0001$ & significant \\
\hline A-pH & 1244.52 & 1 & 1244.52 & 128.40 & $<0.0001$ & \\
\hline B-Time & 504.96 & 1 & 504.96 & 52.10 & $<0.0001$ & \\
\hline C-ozone dosage & 681.48 & 1 & 681.48 & 70.31 & $<0.0001$ & \\
\hline $\mathrm{AB}$ & 54.57 & 1 & 54.57 & 5.63 & 0.0391 & \\
\hline $\mathrm{AC}$ & 943.95 & 1 & 943.95 & 97.39 & $<0.0001$ & \\
\hline $\mathrm{BC}$ & 231.12 & 1 & 231.12 & 23.85 & 0.0006 & \\
\hline $\mathrm{A}^{2}$ & 975.64 & 1 & 975.64 & 100.66 & $<0.0001$ & \\
\hline $\mathrm{B}^{2}$ & 445.24 & 1 & 445.24 & 45.94 & $<0.0001$ & \\
\hline$C^{2}$ & 672.43 & 1 & 672.43 & 69.38 & $<0.0001$ & \\
\hline Residual & 96.92 & 10 & 9.69 & & & \\
\hline Lack of Fit & 95.49 & 5 & 19.10 & 66.62 & 0.0001 & significant \\
\hline Pure Error & 1.43 & 5 & 0.29 & & & \\
\hline Cor Total & 5624.05 & 19 & & & & \\
\hline
\end{tabular}

at alkaline $\mathrm{pH}$ is a result of fast reaction of organic matter with molecular ozone. This was supported by the study of Singh et al. [28] where they suggested that increasing the amount of $\mathrm{OH}$ radicals will destroy the organic compounds more effectively. They reported $85 \%$ of COD removal in cornprocessing wastewater at alkaline $\mathrm{pH}$. The decomposition of aqueous ozone increases with an increase in $\mathrm{pH}$ and this will in turn result in an increase in $\mathrm{OH}$ radicals and simultaneous increase in removal of the pollutant. Garcia et al. [29] had observed a maximu m COD removal of $80 \%$ at alkaline $\mathrm{pH}$ of 9 than at acidic $\mathrm{pH}$ of 3, from dye wastewater. They suggested that hydroxyl radicals had a better ability of organic oxidation. It was also found that as the ozone concentration increased the percentage of COD removal rate simultaneously increased.

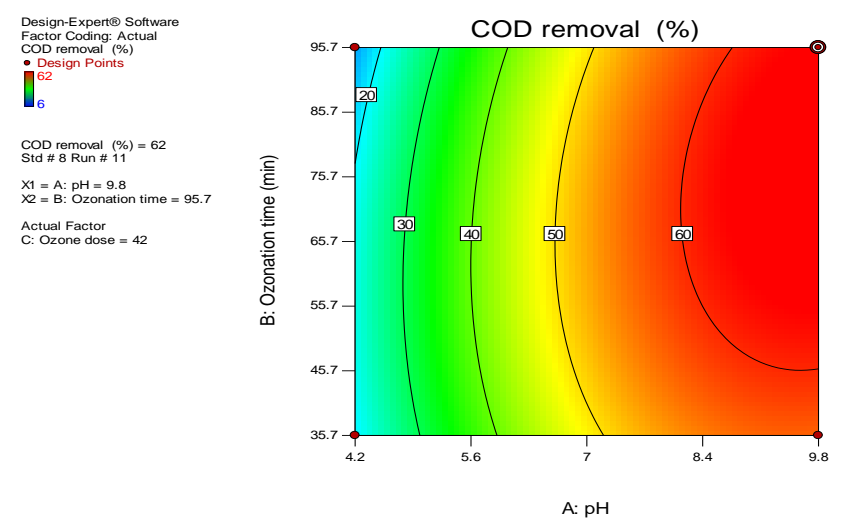

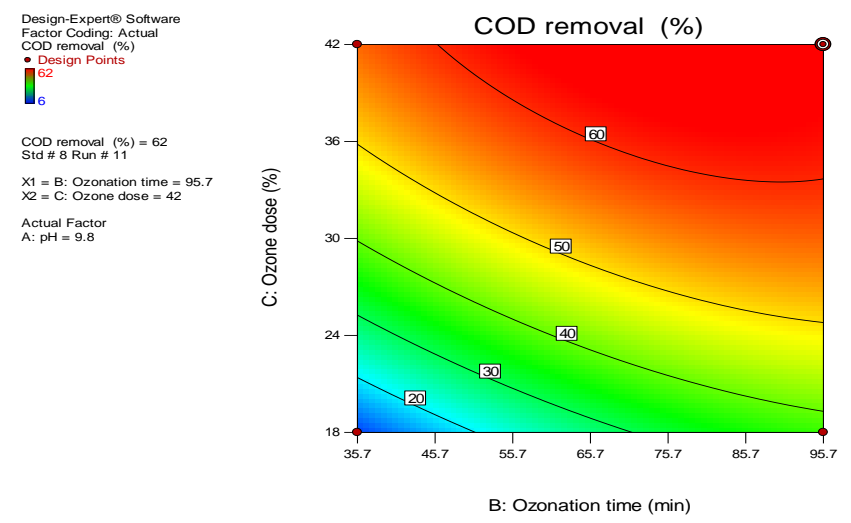

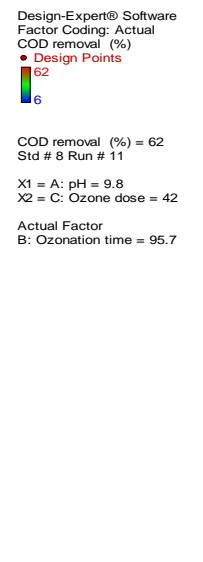

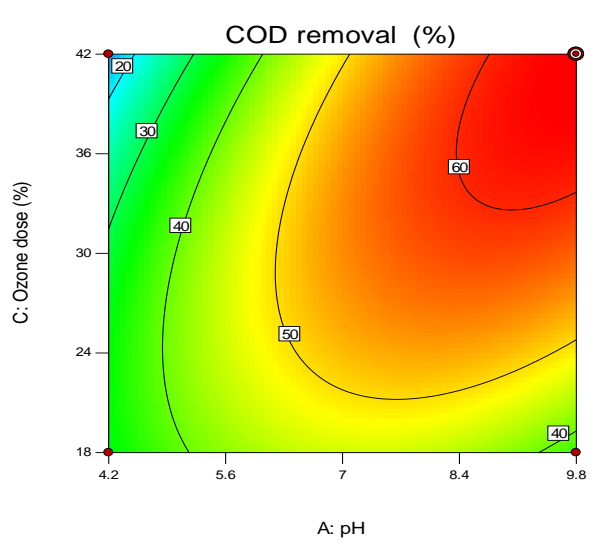

(A) 
Design-Expert $\circledast$ Software

COD removal (\%)

Design points above predicted value 62

COD removal $(\%)=62$

$\mathrm{Std}$ \# 8 Run \# 11
$\mathrm{X}=\mathrm{A}: \mathrm{pH}=9.8$

$\mathrm{X}=\mathrm{B}: \mathrm{O}$ : $\mathrm{zonation}$ time $=95.7$

Actual Factor

C: : zone dose $=42$

COD removal (\%)

- Design points above predicted value 62

COD removal $(\%)=62$

Std \# 8 Run \# 11

$\mathrm{X} 1=\mathrm{A} \cdot \mathrm{PH}=9.8$

dose $=42$

Actual Factor

COD removal (\%)

- Design points above predicted value 62

COD removal $(\%)=62$ Sta \# Run \#11 $X_{2}=$ C. Orone done time $=95$. Actual Factor
A: $\mathrm{pH}=9.8$
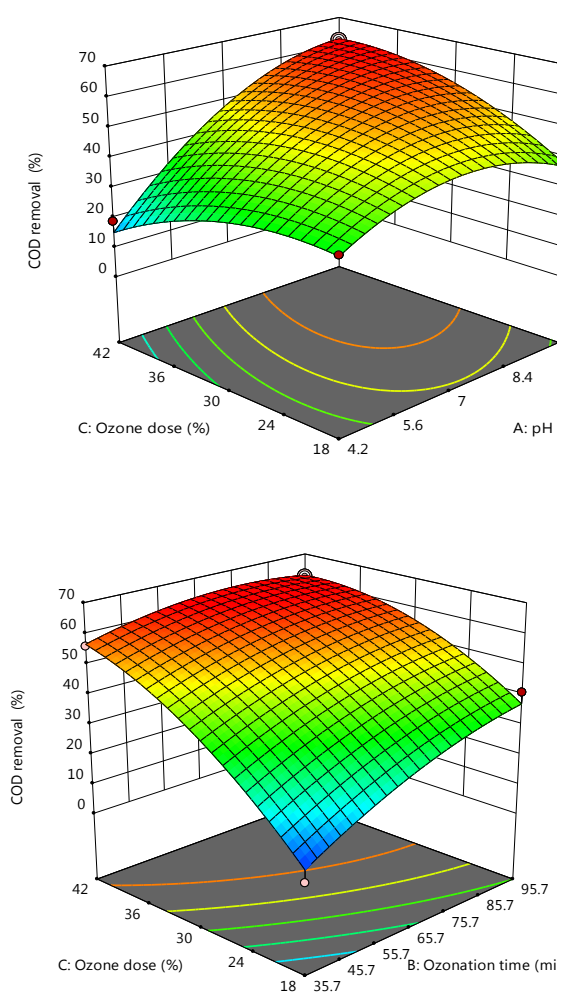

(B)

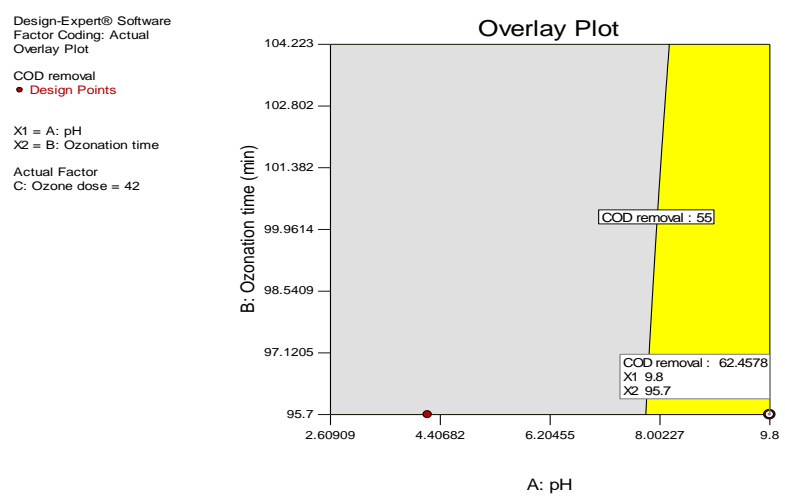

(C)

Figure 2. Maximum $\mathrm{COD}$ removal at $\mathrm{pH}$ 9.8, ozonation time $95.7 \mathrm{~min}$, ozone dose $42 \%$ (A) Contour graphs (B) three dimensional surface plots (C) Overlay plot of the condition

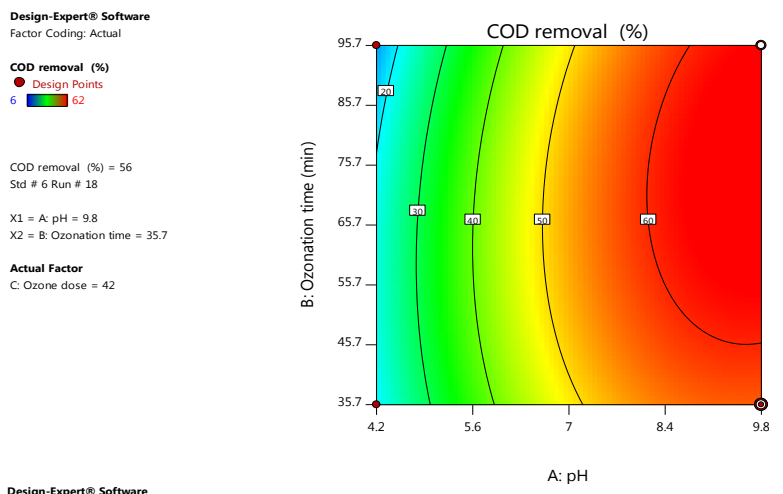

Design-Expertø Software
Factor Coding: Actual COD removal (\%)
0 Design Points
6

$x_{1}=8:$ Ozonation time
$x_{2}=$ c: Ozone dose

Actual Factor
A: $\mathrm{pH}=9.8$

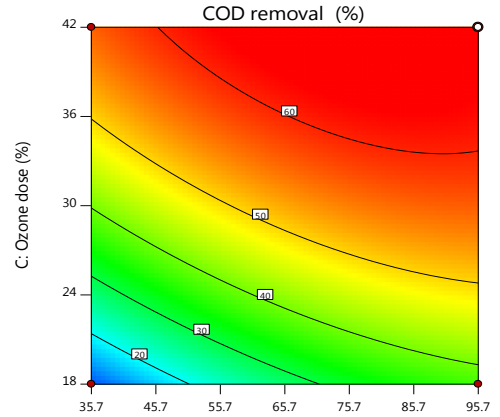

Design-Expert@ Software
Factor Coding: Actual

COD removal (\%)
6 Design Points
62

$x_{1}=A: p H$
$x_{2}=C:$ Ozone dose

Actual Factor
B: Ozonation time $=357$

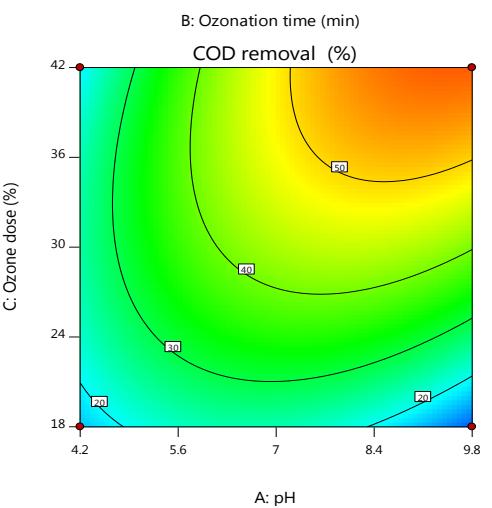

(A)

Design-Expert@ Software

Design points above predicted value

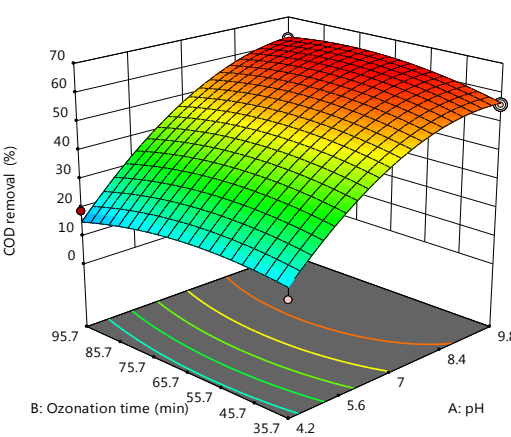

Design-Expertæ Softwar

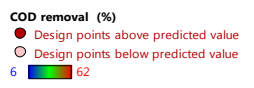

$\operatorname{COD}$ removal $(\%)=56$ Std \# 6 Run \# 18
$X 1=8 \cdot$ Ozonation time $=35.7$ $x 1=8:$ Ozonation time $=357$
$X 2=c:$ Ozone dose $=42$

Actual Factor
A. $\mathrm{pH}=9.8$

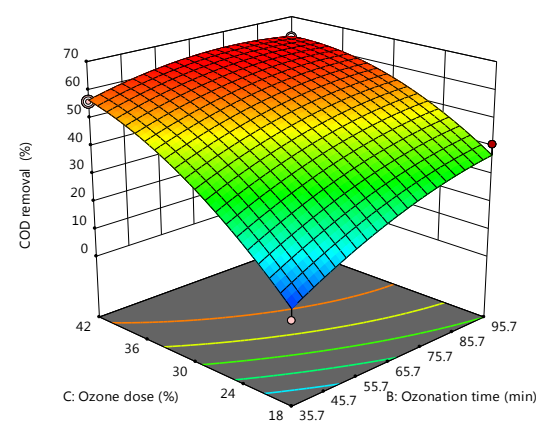



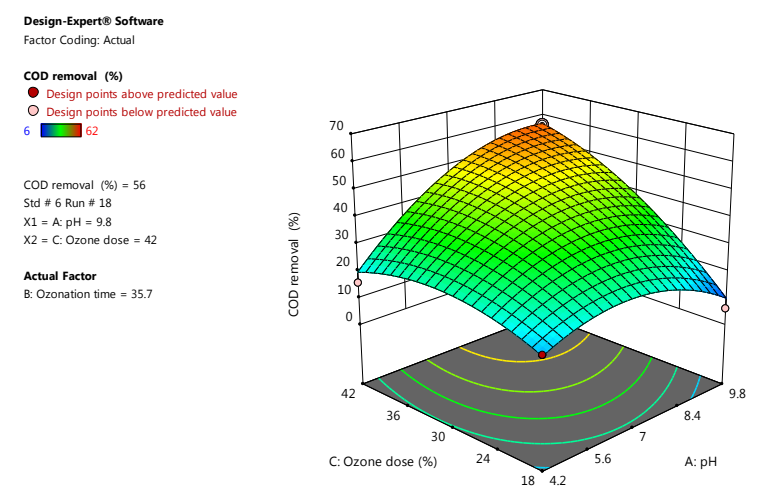

(B)

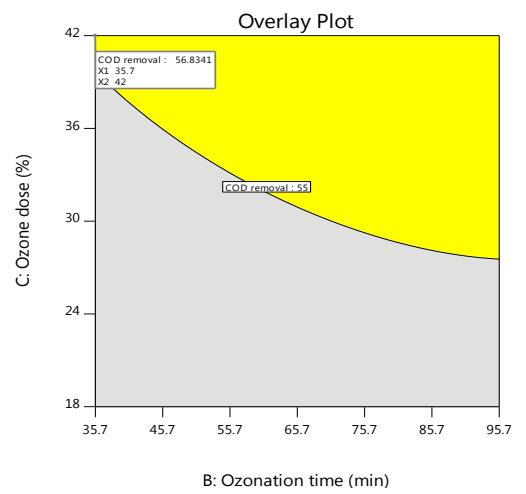

(C)

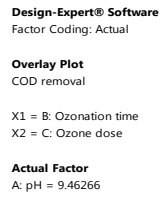

Figure 3. Optimum COD removal at $\mathrm{pH} 9.8$, ozonation time $35.7 \mathrm{~min}$, ozone dose $42 \%$ (A) Contour graphs (B) three dimensional surface plots (C) Overlay plot of the optimized condition

Sreethawong and Chavadej [30] supported this result, and they reported that the COD removal rate increased from $25 \%$ to $50 \%$ when the ozone concentration was increased from 0.3 $\mathrm{g} / \mathrm{h}$ to $1.1 \mathrm{~g} / \mathrm{h}$. The COD removal rate increased from $60 \%$ to $90 \%$ when the ozone dose increased from $7 \mathrm{mg} / \mathrm{min}$ to 33 $\mathrm{mg} / \mathrm{min}$. This is because, an increase in the influent ozone gas concentration results in an increase in aqueous ozone concentration which either directly reacts with organics or decomposes to produce $\cdot \mathrm{OH}$ which in turn reacts with the same. Another study by Terry [31], have indicated that the COD removal efficiency increased to $15 \%$ when the ozone concentration was increased from $0.053 \mathrm{~g} / \mathrm{min} . \mathrm{L}$ to 0.53 $\mathrm{g} / \mathrm{min} . \mathrm{L}$. Thus increasing ozone concentration effectively resulted in enhanced removal of COD. It was found that as ozonation time was increased, the percentage COD removal rate also increased simultaneously. Wang et al. [32] also suggested that the COD reduced from $40 \mathrm{mg} / \mathrm{L}$ to $29.6 \mathrm{mg} / \mathrm{L}$ as the ozone contact time was increased from $1 \mathrm{~min}$ to $4 \mathrm{~min}$. Another study by Ulson et al. [33], have also suggested that the COD value of the dye wastewater was $500 \mathrm{mg} / \mathrm{L}$ when the ozonation duration was $60 \mathrm{~min}$, but the values decreased to $250 \mathrm{mg} / \mathrm{L}$ as the contact time was increased to $100 \mathrm{~min}$. Thus these above mentioned discussions have justified the results of this study.

\section{Effect of ozone on the bacterial count}

Microbial count studies were conducted to find out the efficiency of ozonation for the removal of bacteria present in sago wastewater. Table 5 shows the bacterial count in sago was tewater before and after ozonation. Prior to ozonation the bacterial count was $10 \times 10^{2} \mathrm{CFU} / \mathrm{mL}$ and after ozonation, it was found that there were no bacteria present. This is due to the above mentioned fact of bacterial cell lysis due to ozone gas exposure. Subha and Muthukumar [23] reported that most of the activated sludge microorganisms in the ozonation reactor would be killed and oxidized to organic substances. Those organic substances produced from the sludge ozonation can then be degraded in the subsequent biological treatment. Muhlisin et al. [34] have passed ozone gas for decontamination of Salmonella typhimurium in chicken meat. They observed a reduction in $80-90 \%$ of the CFU of the pathogen due to ozone exposure than control. The effects of gaseous ozone exposure on the bacterial counts and oxidative properties were evaluated in duck and chicken breast meat. Ozone effectively reduced the growth of coliform, aerobic and anaerobic bacteria in both chicken and duck breast [35]. Zhang et al. [36] had examined the mechanism of ozoneinduced damage to Pseudomonas aeruginosa bacterium. They reported that ozone treatment effectively ruptured the bacteria's cell membrane leading to the leakages of cell contents. In this present study, after 20 minutes of ozonation, there were no microorganisms present in the sample. Digital microscopic appearance of wastewater is shown in Figure 4. It was observed that the biomass was dense before ozonation and after ozonation biomass concentration was reduced. These results and substantiations have clearly indicated that bacterial population reduction was steady due to ozone dosages. It can be concluded that ozonation will be an effective method for the inhibition and elimination of microorganis ms.

\section{Selection of optimal levels and estimation of optimum response characteristics}

Optimized values are always desirable to justify the feasibility and practical application possibilities of a particular treatment process in large scale. Optimum level of various parameters obtained after examining the response curves and contour plots were $\mathrm{pH}$ of 9.8 , ozone dose $42 \%$ and ozonation time 35.7 min where an experimental maximum removal of $56 \%$ and predicted removal of 56.7 were obtained.

TABLE 5. Initial and final bacterial count in the effluent

\begin{tabular}{lcc}
\hline \multirow{2}{*}{ Dilution factor } & \multicolumn{2}{c}{ No. of colonies } \\
\cline { 2 - 3 } & Before Ozonation & After Ozonation \\
\hline $10^{2}$ & $10 \mathrm{CFU} / \mathrm{mL}$ & $\mathrm{Nil}$ \\
$10^{3}$ & $5 \mathrm{CFU} / \mathrm{mL}$ & $\mathrm{Nil}$ \\
\hline
\end{tabular}
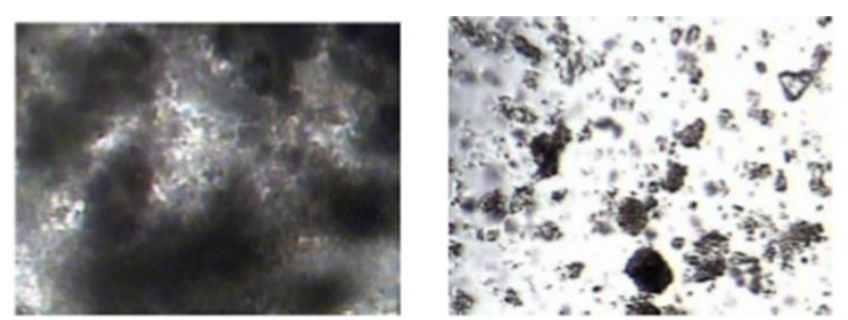

Figure 4. Microscopic appearance of the biomass in the wastewater (A) before ozonation (B) after ozonation 


\section{SUMMARY}

The increase in number of the sago industries has been creating a threat to the environment. The highly organic wastewater has been polluting not only the water bodies but also the land. Ozonation process was successfully employed for treatment of the sago wastewater in this research study. A central composite design was successfully employed for experimental design, analysis of results and optimization of the operating parameters for maximizing the COD removal from sago wastewater by ozonation. It also helps to understand the interaction effect of the variables on responses. The COD removal was found to be affected by $\mathrm{pH}$, ozonation time and ozone dose. A maximum COD removal of $62.45 \%$ was predicted and $62 \%$ was obtained through experimental studies. But, maximum COD removal was only obtained when all the parameters were provided at almost high ranges like $\mathrm{pH}$ of 9.8, ozonation time of $95.7 \mathrm{~min}$ and ozone dose of $42 \%$. The optimization of the analysed responses demonstrated that best results for COD removal (experimental 56 and predicted $56.7 \%$ ) were obtained at a $\mathrm{pH}$ of 9.8 , ozonation time of $35.7 \mathrm{~min}$ and ozone dose of $42 \%$. The results of this study can be of considerable significance for choosing appropriates operating factors at optimum levels with minimum effort and time. The present study and its results demonstrated the applicability of ozonation process for effective organic load removal in sago wastewater.

The authors do not have any conflict of interest.

\section{ACKNOWLEDGEMENTS}

The authors would like to acknowledge the funding support from NSC (National Science Council) Taiwan under the MOST (Ministry of Science and Technology) project number MOST 106-2218-E-027-014-MY2 for the Design Expert software used in this research study.

\section{REFERENCES}

1. Muthukumar, M. and Sangeetha, T., 2014. The harnessing of bioenergy from a dual chambered microbial fuel cell (MFC) employing sago-processing wastewater as catholyte. International Journal of Green Energy. 11, 161-172.

2. Sangeetha, T., Muthukumar., 2012. Influence of electrode material and electrode distance on bioelectricity production from sago-processing wastewater using microbial fuel cell. Journal of Environmental Progress and Sustainable Energy. 32 (2): 390-395.

3. Priya, M., Meenambal, T., Balasubramanian, N., and Perumal, B., 2015. Comparative Study of Treatment of Sago Wastewater using HUASB Reactor in the Presence and Absence of Effective Microorganisms. Procedia Earth and Planetary Science. 11, 483-490.

4. Monisha, T., S. Rajakumar, and P. M. Ayyasamy., 2013. Microbial-Treated Sago Mill Effluent: A Potential Water Resource for Agroecosystem Management. In: Velu R. (eds) Microbiological Research In Agroecosystem Management. Springer. India.

5. Elaiyaraju, P., Partha, N., 2012. Biogas Production from Sago (Tapioca) Wastewater Using Anaerobic Batch Reactor. Energy and Environment. 23, 631-645.

6. Parthiban, R., Iyer, P.V.R. and Sekaran, G., 2007. Anaerobic tapered fluidized bed reactor for starch wastewater treatment and modeling using multilayer perceptron neural network. Journal of Environmental Sciences. 19, 1416-1423.

7. Gopalakrishna, K., 2007. Performance studies of hybrid reactor for the treatment of sago wastewater. Environmental Information Archives. 5: 415-421.

8. Balasundaram, N., Meenambal, T., Balasubramanium, N., and Loganath, R., 2014. Comparative Study of Different Media in the Treatment of Sago Wastewater using HUASB Reactor. Nature Environmental Pollution Technology. 13(3), 511-516.

9. Rajasimman, C., Karthikeyan, M., 2007. Starch Wastewater Treatment in a Three Phase Fluidized Bed Bioreactor with Low Density Biomass Support. Journal of Applied Sciences Environmental Management. 11, 97 -102 .

10. Savitha, S., Sadhasivam, S., Swaminathan, K., Lin, F. H., 2009. A prototype of proposed treatment plant for sago factory effluent. Journal of Cleaner Production. 17: 1363-1372.

11. Rajesh Banu, J., Yeom, I. T., Esakkiraj, S., NareshKumar and Logakanthi, S., 2008. Bio management of sagosludge using an earthworm, Eudrilus eugeniae. Journal of Environmental Biology. 29, 143-146.

12. Maheshwari, P.,Venilamani, N., Madhavakrishnan, S., Syed Shabudeen, P.S., Venckatesh,R and Pattabhi, S., 2008. Utilization of Sago Waste as an Adsorbent for the Removal of $\mathrm{Cu}$ (II) Ion from Aqueous Solution. Journal of Chemistry. 5, 233-242.

13. Behin, J., Farhadian, N., 2016. Response surface methodology for ozonation of trifluralin using advanced oxidation processes in an airlift photoreactor. Applied Water Sciences. 1-10.

14. Asaithambi, P., Susree, M., Saravanathamizhan, R., and Matheswaran, M., 2012. Ozone assisted electrocoagulation for the treatment of distillery effluent. Desalination, 297, 1-7.

15. Huerta-Fontela, M., Galceran, M. T., and Ventura, F., 2011. Occurrence and removal of pharmaceuticals and hormones through drinking water treatment. Water Research. 45, 1432-1442.

16. Rodríguez, L., Oller, I., Klamerth, N., Agüera, A., Rodríguez, E. M., and Malato, S., 2013. Application of solar AOPs and ozonation for elimination of micro pollutants in municipal wastewater treatment plant effluents. Water research. 47 (4), 1521-1528.

17. Anam, A., Abdul, A., and Wan, M., 2015. Advanced oxidation processes for in-situ production of hydrogen peroxide/hydroxyl radical for textile wastewater treatment: a review. Journal of Cleaner Production. 87, 826-838.

18. Amr, S. S. A., Aziz, H. A., and Bashir, M. J., 2014. Application of response surface methodology (RSM) for 
optimization of semi-aerobic landfill leachate treatment using ozone. Applied Water Sciences. 4, 231-239.

19. Dutta, S., Ghosh, A., Moi, S. C., and Saha, R., 2015. Application of response surface methodology for optimization of reactive azo dye degradation process by Fenton's oxidation. International Journal of Environmental Sciences and Development. 6, 818-823.

20. Wambui, J. M., Karuri, E. G., and Wanyoike, M. M., 2017. Application of Response Surface Methodology to Study the Effects of Brisket Fat, Soy Protein Isolate, and Corn starch on Nutritional and Textural Properties of Rabbit Sausages. International Journal of Food Science.2017. Article ID 7670282, 11 pages https://doi.org/10.1155/2017/7670282

21. Zhao, X., Wang,L., Ma, F., Bai, S., Yang, J., and Qi, S., 2017. Pseudomonas sp. ZXY-1, a newly isolated and highly efficient atrazine-degrading bacterium, and optimization of biodegradation using response surface methodology. Journal of Environmental Sciences. 54, 152-159.

22. APHA, Standard methods for the examination of water and wastewater, $21^{\text {st }}$ ed. American Public Health Association, New York, USA, 2005.

23. Subha, B. and Muthukumar, M., 2012. Optimization of ozonation process for the reduction of excess sludge production from activated sludge process of sago industry wastewater using central composite design. The Scientific World Journal. 2012 (Article ID 239271).

24. Chen, F., Yuan, Y., Chen, C., Zhao, Y., Tan, W., Huang, C., Wang, A. 2016. Investigation of colloidal biogenic sulfur flocculation: Optimization using response surface analysis. Journal of Environmental Sciences, 42, $227-$ 235.

25. Sujatha, K., and Kumar, K., 2011. Variations on physicochemical characteristics of waste water from Sago industries of Salem, Tamil nadu. Journal of Ecotoxicology and Environmental Monitoring. 23, 185190.

26. Subha, B., Song, Y. C., and Woo, J. H., 2017. Bioremediation of contaminated coastal sediment: optimization of slow release biostimulant ball using response surface methodology (RSM) and stabilization of metals from contaminated sediment. Marine Pollution Bulletin, 114, 285-295.
27. Modhirshahla, N., Behnajady, M.A, Kooshaiian, S., 2007. Investigation of the effect of different electrode connections on the removal efficiency of tartrazine from aqueous solutions by electrocoagulation. Dyes and Pigments. 74, 249-257.

28. Singh, S., Fan, M., Brown, M.C., 2008. Ozone treatment of process water from a dry-mill ethanol plant. Bioresource Technology. 99: 1801-1505.

29. García-Orozco, V. M., Barrera-Díaz, C. E., Roa-Morales, G., and Linares-Hernández, I., 2016. A Comparative Electrochemical-Ozone Treatment for Removal of Phenolphthalein. Journal of. Chemistry. 2016 (Article ID 8105128).

30. Sreethawong, T., Chavadej, S., 2008. Color removal of distillery wastewater by ozonation in the absence and presence of immobilized iron oxide catalyst. Journal of Hazardous Material. 155: 486-493.

31. Terry, P. A. 2010. Application of ozone and oxygen to reduce chemical oxygen demand and hydrogen sulfide from a recovered paper processing plant. International Journal of Chemical Engineering. 2010: 1-6.

32. Wang, S., Ma, J., Liu, B., Jiang, Y., Zhang, H. 2008. Degradation characteristics of secondary effluent of domestic wastewater by combined process of ozonation and biofiltration. Journal of Hazardous Matererials. 150: 109-114.

33. Ulson, S. M. D. A. G., Bonilla, K. A. S., and De Souza, A. A. U., 2010. Removal of COD and color from hydrolyzed textile azo dye by combined ozonation and biological treatment. Journal of Hazardous Matererials. 179, 35-42.

34. Muhlisin, M., Cho, Y., Choi, J. H., Hahn, T. W., and Lee, S. K., 2015. Bacterial counts and oxidative properties of chicken breast inoculated with Salmonella Typhimurium exposed to gaseous ozone. Journal of Food Safety. 35, 137-144.

35. Muhlisin, M., Utama, D. T., Lee, J. H., Choi, J. H., and Lee, S. K., 2016. Effects of gaseous ozone exposure on bacterial counts and oxidative properties in chicken and duck breast meat. Journal of Food Sciences and Animal Resources, 36, 405-411.

36. Zhang, Y. Q., Wu, Q. P., Zhang, J. M., and Yang, X. H., 2011. Effects of ozone on membrane permeability and ultrastructure in Pseudomonas aeruginosa. Journal of Applied Microbiology. 111, 1006-1015.

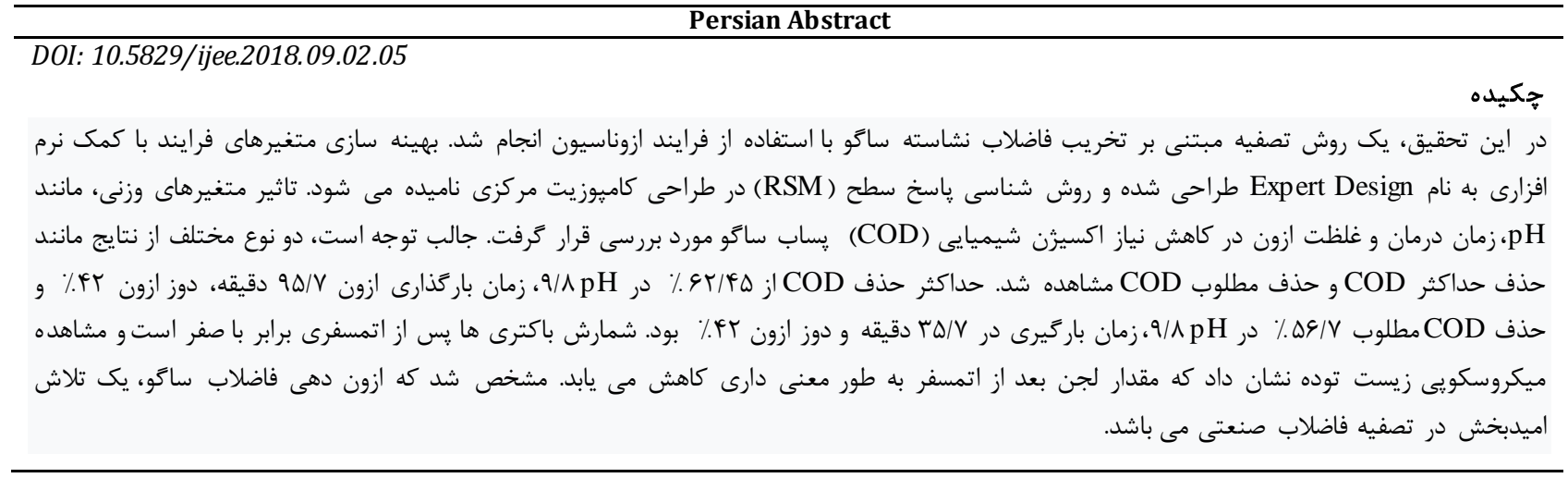

